\title{
A systematic review of the characteristics, phytonutritive, and therapeutic potential of the date palm fruit (Phoenix dactylifera)
}

\author{
GeEtIKa SHARMA $^{1}$, VIPASha Sharma ${ }^{1}$, TUlika Mishra ${ }^{2}$ * \\ ${ }^{1}$ Chandigarh University, Department of Biotechnology, Ludhiana - Chandigarh State Hwy, Punjab, India \\ ${ }^{2}$ Xavier University, Aruba, Dutch Caribbean
}

\begin{abstract}
Plants and their products are nature's gift to humans and animals. They help them lead a healthy, disease free life. Date palm counts for more than 3000 different cultivars around the world. The therapeutic value of the date plant is due to the presence of various phytochemical and bioactive compounds in almost every part of it. In addition to being a good source of dietary fiber, dates are free from sodium, fat, and cholesterol, which makes them a suitable dietary supplement for reducing the risk of heart diseases and cancer. Traditional systems of medicine use dates to treat a variety of ailments due to their antioxidant, antimicrobial, antimutagenic, anti-inflammatory, anticancer, gastroprotective, hepatoprotective, nephroprotective, and immunostimulant activities as revealed by preclinical studies. Owing to its nutritious and medicinal properties, the fruit of the date palm (Phoenix dactylifera L.) has been referred to as a "super food" multiple times in the Quran. Interestingly, date palms have been honored by Jews, Christians, and Muslims as a symbol of honesty and righteousness. This review provides an overview of the nutritional and phytochemical composition of the fruit of the $P$. dactylifera plant, summarizing the history, symbolism, systematic and botanical distribution, and outlines their potential for medical applications, and health benefits.
\end{abstract}

Key words: antioxidant, nutritional value, Phoenix dactylifera, phytochemicals, therapeutic importance

\section{Introduction}

Phoenix dactylifera, also known as the date palm, is a monocotyledonous plant within the Arecaceae family (syn. Palmaceae) that currently includes 181 genera and around 2600 species restricted to tropical and subtropical climates (Christenhusz and Byng, 2016). The genus Phoenix is composed of 14 species, the most famous being the widely cultivated date palm, $P$. dactylifera (WCSP, 2013). Although its place of origin is unknown, it probably originated in lands around Iraq (Morton, 2011) and can nowadays be found mostly in the hot regions of North Africa and the Middle East (Baliga et al., 2011). The botanical name of the date palm, P. dactylifera L., is presumably derived from the Phoenician name "phoenix," forthe date palm and "dactylifera", derived from the Greek word "daktulos" (also from the
Hebrew word "dachel") meaning a finger, illustrating the fruit's form or shape. Another source refers this botanical name to the legendary Egyptian bird, "Phoenix", which lived for 500 years and cast itself into a fire from which it rose with renewed youth (Pliny, 1489; Van Zyl, 1983). The resemblance of the date palm, which can also regrow after fire damage, to the legendary Phoenix may be the reason why the mythical bird and the date palm share the same name (Popenoe, 1973). Apart from being a concentrated energy food that can be easily carried along on long journeys across the desert, it also creates a more amenable habitat for the people to live by providing shade and protection from desert winds. Practically all parts of the palm are useful as they yield a variety of products for use in agricultural production and domestic needs (Al-Gboori and Krepl, 2010). Date palm

*Corresponding author: Xavier University, Aruba, Dutch Caribbean; e-mail: tulikares@gmail.com 
fruits have traditionally been used to treat various types of ailments; furthermore, their consumption is considered good for health. The use of $P$. dactylifera includes the use of the trunk, usually for wood veneer or combustionas no plaits can be produced due to poor wood quality; the leaves are used for the production of paper, carton and glue plates, and the fruit provides seed and pulp.

\section{Geographical distribution}

The genus Phoenix (Coryphoideae Phoeniceae) is native to the tropical and subtropical regions of Africa and Southern Asia (Munier, 1973). Over 600 different cultivars of the date fruit have been reported based on the shape and organoleptic properties (Baliga et al., 2011). Table 1 presents twelve different species of the Phoenix genus and their geographical distribution.

The cultivation of dates can be successfully achieved in areas with mild temperatures $\left(25\right.$ to $29^{\circ} \mathrm{C}$ ) during flowering (February to April), and long hot summers for fruit ripening (May to August). Date growth is limited by inadequate heat conditions, high rainfall, high atmospheric humidity during the later development stages, or during blossoming. Therefore, it is confined to arid and semi-arid regions. However, water requirements of date palms are very high, $20000-30000 \mathrm{~m}^{3} \cdot \mathrm{ha}^{-1} \cdot$ year $^{-1}$ (Rehm and Espig, 1977).

P. dactylifera has been cultivated around the world and reportedly naturalized in Australia, Spain, North Africa, the Canary Islands, Madeira, Cape Verde, the Sahal region of Africa, Mauritius, Reunion, Afghanistan, Pakistan, India, Israel, Iran, China (Fujian, Guangdong, Guangxi, Yunnan), Fiji, New Caledonia, the USA (California, Nevada, Arizona, Florida, Puerto Rico), northern Mexico, El Salvador, Leeward Islands, Cayman Islands, and Dominican Republic (Nixon, 1951). The Spanish were the first to introduce date palms outside the Arabian Peninsula, North Africa, and the Middle East/South Asia carrying them to America. The growth of dates is widespread in arid regions between $15^{\circ} \mathrm{N}$ and $35^{\circ} \mathrm{N}$, from Morocco in the west to India in the east (Zaid and De Wet, 2002).

\section{Physiology of $\boldsymbol{P}$. dactylifera}

$P$. dactylifera is a tall, evergreen, unbranched palm with a straight and simple stem that reaches a height of 9 to $18 \mathrm{~m}$ and bears a head of 40 to 80 glaucous pinnate leaves, 2-3 $\mathrm{m}$ long, and a number of branching spadices, each of which on the female tree bears 180 to 200 fruits (Sawaya et al., 1983). There are several botanical features that make the date palm unique among fruit trees. Its total height,including the stem and leaves, can exceed $20 \mathrm{~m}$ and these trees can survive over a hundred years. It has been revealed that date palms can survive under harsh conditions such as extended drought, high salinity levels, and heat (Al-Yahyai and Manickavasagan, 2012).

Being a monocotyledon, the date palm has no taproot, its root system is fasciculate, and its roots are fibrous and similar to those of the maize plant. Secondary roots appear on the primary root which develop directly from the seed. Although the date palm requires a wellaerated soil for maximum yield, the roots can survive submergence in water for considerable periods of time, possibly due to the structure of the roots that may enable them to conduct some air downward to the absorbing rootlets (Rehm and Espig, 1977). The date palm root system is divided into four zones: zone 1 - respiratory zone, zone 2 - nutritional zone, zone 3 - absorbing zone, and zone 4 - the largest zone, dependent on underground water. At shallower depths, it becomes difficult to distinguish between zone 3 and zone 4 , but when the underground water is deep, the roots of zone 4 can reach a greater depth. Pinnated leaves and conduplicate leaflets with acute tips are the characteristic features of the date palm (Uhl and Dransfield, 1987). Date palm leaves (fronds) remain intact and act as heat insulators; so, during cultivation, theold leaves have to be removed manually.

The date fruit is a single, oblong, terette, one-seeded berry, with a terminal stigma, a fleshy pericarp, and a membranous endocarp present between the seed and the flesh. Endosperm, a supply of food inside the seed coat, is composed of $65 \%$ hemilloze, $7 \%$ oil, $6 \%$ protein, enzyme cytoze, and pulp. Being a good source of dietary fiber (DF), proteins, minerals, and phenolic compounds with antioxidant activity, date seeds can be used as a functional food ingredient. This explains the potential uses of date seed in different industries (Golshan et al., 2017).

Immature fruits are green, yellow, or red. During maturation, the fruits ripen in 6-8 months through four distinct stages; immature green, the mature full-colored, the soft brown, and the hardraisin-like stage (in Arabic, these stages are termed Kimri, Khalal, Rutab, and Tamr, respectively) (Al-Shahib and Marshall, 2003). Date palm 
Table 1. Twelve species of the Phoenix genus along with their geographical distribution (Chevalier, 1952)

\begin{tabular}{l|c|l}
\hline \multicolumn{1}{c|}{ Species } & Common name & \multicolumn{1}{c}{ Distribution } \\
\hline Phoenix dactylifera L. & date palm & $\begin{array}{l}\text { Mediterranean countries, Africa, and parts of Asia, introduced } \\
\text { in North America, and Australia }\end{array}$ \\
\hline$P$. atlantica Chev. & - & Occidental Africa and Canary Islands \\
\hline$P$. canariensis & canary palm & Canary Islands and Cape Verde \\
\hline$P$. reclinata Jacq. & dwarf palm & Tropical Africa (Senegal and Uganda), and Yemen (Asia) \\
\hline$P$. sylvestris Roxb. & wild datepalm or sugar palm & India and Pakistan \\
\hline$P$. humilis Royle & - & India, Burma, and China \\
\hline$P$. hanceana Naudin & - & Meridional China, and Thailand \\
\hline$P$. robelinic O’Brein & - & Sri Lanka, Toukin, Annam, Laos, and Thailand \\
\hline$P$. farinifera Roxb. & pigmy palm & India, Sri Lanka, and Annam \\
\hline$P$. rupicola Anders & rocky date palm & India \\
\hline$P$. acaulis Roxb. & dwarf palm & Bangladesh and India \\
\hline$P$. paludosa Roxb. & Hental or Juliana palm & Bangladesh, Tenasherim, Andaman and Nicobar, and Thailand \\
\hline
\end{tabular}

fruits consist of three essential parts: date flesh which constitutes 85 to $90 \%$ of date fruit weight, date seed, or pit which constitutes about $6 \%$ to $12 \%$ of the total weight of the mature date, and skin which is a thin layer surrounding the fruit to protect the fleshy part (El-Sohaimy and Hafez, 2010; Jassim and Naji, 2010).

Date palm is a dioecious specie with male and female flowers being produced in clusters on separate palms. Flowers are borne in bunches at the top of the tree. Pistillate and staminate flowers are rarely produced on the same spike, while the presence of hermaphrodite flowers in the inflorescence has also been reported. Palms carrying both unisexual and hermaphrodite flowers are known as polygamous (Chandler, 1958).

Only the female trees produce fruit. Interestingly, one male tree can produce enough pollen to pollinate 40-50 female trees. In order to secure a high quality yield of date palm, it is extremely important to select suitable male palms for pollination to achieve the metaxenia effect which ensures a precise, definite, and direct influence of the male parent on the development of the date fruit (Swingle, 1928).

\section{Symbolism of date palm}

It is believed (Zohary and Hopf, 2000) that dates have been cultivated in North Africa and the Middle East for at least 5000 years. Without dates, no large human populations could have survived in the desert regions.
Dates had great spiritual, cultural, feeding, and industrial value in ancient Egypt, as well as an important influence on the history of the people of the Middle East. References relating to date palm are found in ancient Egyptian, Syrian, Libyan, and Palestinian writings (Nixon, 1951; Popenoe, 1973).

Various names were given to the date palm in ancient Egypt, as cited in hyperglyphic symbols - "Buno", "Phuno", "Bni”, "Bnr", "Benrt", "Amt", "Bnrit", and "Bniui" for date juice. Ancient Egyptians venerated this tree as representing fertility. It has been honored by Jews, Christians, and Muslims as a symbol of honesty and righteousness. The Carthaginians depicted the date palm on coins and monuments, and the Greeks and Romans used it as a victory decoration in pageants. In the Christian tradition, palm fronds have long been an emblem of peace and were, and still are, being used on Palm Sunday to commemorate the entry of Jesus into Jerusalem. Palm leaves were also carried by every attendant of the solemn morning procession, along with fragments of fronds, the leaflets of which had been painted in various decorative shapes (Bircher, 1990). The date palm tree was depicted in Hebrew drawings and was a symbol evoking grace and elegance in women. Jews named their girls "Tamara" (derived from the word Tamr) as they wished them to become smart, tall, pretty, and fertile like the date palm (Qudama, 1985). 


\section{Nutritional potential of dates}

The date palm ( $P$. dactylifera L.) plays a vital role in the economic, social, and cultural life of the people in the Arabian region. Dates were considered to be one of the most appropriate foods for invading armies in the vast deserts of the Arabian Peninsula. The species showed generous yields, resisting the harsh climatic and environmental conditions of the area, while no other type of tree has been as successful under the same conditions (Al-Fuhaid, 2006). The importance of date palm culture is well recognized for its high nutritive, economic, and social values, especially in arid and semi-arid areas where it plays an important role in influencing the microclimate in a way that enhances the production of other agricultural crops. Worldwide production, utilization, and industrialization of dates are increasing continuously (Botes and Zaid, 2002). Dates can be used in a variety of ways; dry or soft dates are eaten out of hand or may be seeded, and stuffed or chopped. Their use with cereals in puddings, bread, cakes, cookies, ice creams, and candy bars enhances the nutritive value of these foodsand also adds to their flavor (El-Sohaimy and Hafez, 2010). The ability of dates to provide essential nutrients like proteins $(5.22 \%)$, fiber $(16.2 \%)$, carbohydrates $(62.5 \%)$, fat $(8.49 \%)$, and minerals, makes them an ideal food for all age groups (Al Farsi et al., 2005; Vyawahare et al., 2009). Fresh dates have the best nutrient score among fresh apricots, cranberries, figs, green grapes, and plums. A date-based diet, due itshigh sugar content, is a very high-energy diet (as high as $65-75 \%$ of the fruit weight), with simple reducing sugars like glucose and fructose, and negligible amounts of a non-reducing sugar like sucrose, depending on the stage of the fruit development and the date palm cultivar (Vinson et al., 2005).

\section{Minerals and vitamins}

The presence of macro minerals such as $\mathrm{Ca}, \mathrm{P}, \mathrm{Mg}$, and $\mathrm{K}$ and micro minerals such as $\mathrm{Fe}, \mathrm{Zn}, \mathrm{Cu}, \mathrm{Mn}$, and Se in dates makes them one of the richest sources of dietary minerals as compared to other commonly consumed fruits (Al-Shahib and Marshall, 2003; Al-Farsi et al., 2005; Alwarthan and Alswaidan, 1995). Table 2 presents a comparison of the amounts of minerals present in fresh dates and in other fruits that are generally consumed in the USA. Dates are a reasonable and mo- derate source of vitamins such as riboflavin, niacin, pyridoxal, and folate as $100 \mathrm{~g}$ of dry dates provide over $9 \%$ of the ecommended Daily Allowance/Adequate Intake (RDA/AI) for adults, while thiamine, retinol, and ascorbic acid are found in low concentrations in dried dates, as $100 \mathrm{~g}$ of dates provide $<7 \%$ of the daily RDA (Baliga et al., 2011). Date fruits bear high amount of choline and its metabolite betaine, grouped under the vitamin B class, which are important for the synthesis of acetylcholine, cell membrane signaling (phospholids), lipid transport (lipoproteins), and methyl-group metabolism (homocysteine reduction) (Penry and Manore, 2008).

\section{Dietary fiber}

Regular consumption of adequate amounts of foods rich in DFs helps prevent many chronic diseases such as coronary heart disease (Liu et al., 1999), stroke (Steffen et al., 2003), hypertension (Whelton et al., 2005), diabetes (Montonen et al., 2003), obesity (Lairon et al., 2005), and certain gastrointestinal disorders (Petruzziello et al., 2006). Date fruits contain more than twicethe amount of DF than any other fruit (Vayalil, 2012). Many researchers analyzed the fiber content in different cultivars of dates and reported thatthe total fiber content varied from $1-11.4 \%(\mathrm{w} / \mathrm{w})$ depending on the cultivar and methods of analysis (Al-Shahib and Marshall, 2003; Al-Farsi et al., 2005). A study found that the fleshes of Deglet-Nour and Allig cultivars had, respectively, 14.4\% and $18.4 \%$ of total $\mathrm{DF}$ (on dry matter basis: DM) , and the major fraction of the total DF comprised $9.19 \%$ and $11.7 \%$ of insoluble DF for Deglet-Nour and Allig, respectively (Elleuch et al., 2008).

\section{Phytochemical profile and antioxidant potential of the fruit of $P$. dactylifera}

Date fruits arealso a rich source of phytochemicals like flavonoids, carotenoids, phenolic acids, sterols, procyanidins, and anthocyanins and thus, owing to their immense nutritional and phytochemical value, these fruits can be considered as an important part of the daily diet (Benmeddour et al., 2013; Baliga et al., 2011). Owing to the presence of antioxidant phytoconstituents, the use of dates in traditional medicine for the treatment of hypertension, artherosclerosis, microbial infections, constipation, diabetes, and cancer is well understood (Tahraoui et al., 2007). The antioxidant activity of medicinal 
Table 2. A comparison of mineral content between dry date fruits and other fruits consumed in the USA (modified from USDA National Nutrient Database for Standard Reference Release 21 accessed in 2008)

\begin{tabular}{l|c|c|c|c|c|c|c}
\hline \multicolumn{1}{c|}{ Minerals } & Units & Apple & $\begin{array}{c}\text { Dates: } \\
\text { Deglet Nour }\end{array}$ & $\begin{array}{c}\text { Dates: } \\
\text { Medjool }\end{array}$ & Navel oranges & Blueberries & Cranberries \\
\hline Calcium [Ca] & $\mathrm{mg}$ & 6.00 & 39.00 & 64.00 & 43.00 & 6.00 & 8.00 \\
\hline Iron [Fe] & $\mathrm{mg}$ & 0.12 & 1.02 & 0.90 & 0.13 & 0.28 & 0.25 \\
\hline Magnesium [Mg] & $\mathrm{mg}$ & 5.00 & 43.00 & 54.00 & 11.00 & 6.00 & 6.00 \\
\hline Phosphorus [P] & $\mathrm{mg}$ & 11.00 & 62.00 & 62.00 & 23.00 & 12.00 & 13.00 \\
\hline Potassium [K] & $\mathrm{mg}$ & 107.00 & 656.00 & 696.00 & 166.00 & 77.00 & 85.00 \\
\hline Sodium [Na] & $\mathrm{mg}$ & 1.00 & 2.00 & 1.00 & 1.00 & 1.00 & 2.00 \\
\hline Zinc [Zn] & $\mathrm{mg}$ & 0.04 & 0.29 & 0.44 & 0.08 & 0.16 & 0.10 \\
\hline Copper [Cu] & $\mathrm{mg}$ & 0.03 & 0.21 & 0.36 & 0.04 & 0.06 & 0.06 \\
\hline Manganese [Mn] & $\mathrm{mg}$ & 0.04 & 0.26 & 0.30 & 0.03 & 0.34 & 0.36 \\
\hline Fluoride [F] & $\mathrm{mg}$ & 3.30 & 0.00 & 0.00 & 0.00 & 0.00 & 0.00 \\
\hline Selenium [Se] & $\mathrm{mg}$ & 0.00 & 3.00 & 0.00 & 0.00 & 0.10 & 0.10 \\
\hline
\end{tabular}

Table 3. Total phenolic content in four date cultivars

\begin{tabular}{c|c|c}
\hline $\begin{array}{c}\text { Series } \\
\text { number }\end{array}$ & Date cultivar & $\begin{array}{c}\text { Total phenolics } \\
\text { [mg of CAE } \cdot 100 \mathrm{mg}^{-1} \text { fresh weight] }\end{array}$ \\
\hline 1 & Bunarinja & $34.90 \pm 0.15^{\mathrm{a}}$ \\
\hline 2 & Fard & $34.58 \pm 0.20^{\mathrm{a}}$ \\
\hline 3 & Khasab & $35.84 \pm 0.04^{\mathrm{a}}$ \\
\hline 4 & Khalas & $32.24 \pm 0.21^{\mathrm{b}}$ \\
\hline
\end{tabular}

Total phenol as caffeic acid equivalent $(\mathrm{CAE})$ is expressed as mean $\pm \mathrm{SD}$, $n=3$; the means within a column with no common letter ("a" or "b") differ significantly $(P<0.05)$; source: Al Harthi et al., 2015

plants is attributed to the content of phenolic compounds that are secondary metabolites produced in the shikimic acid and pentose phosphate pathway of plants through phenylpropanoid metabolization (Randhie et al., 2004).

Ripe date fruits contain numerous phenolic phytoconstituents like p-coumaric, ferulic and sinapic acids, and some cinnamic acid derivatives (Abdelhak et al., 2005). In a recent study, the quantification of phenolic compounds of four date palm cultivars by preliminary high performance liquid chromatography (HPLC) analysis revealed the presence of phenolic acids like gallic acid, caffeic acid, p-coumaric, and syringic acid in different proportions as mentioned in Table 3 (Al Harthi et al., 2015). In another study, eight phenolic acids including gallic acid, protocatechuic acid, p-hydroxybenzoic acid, vanillic acid, caffeic acid, syringic acid, p-coumaric acid, and ferulic acid were identified in dried Tunisian date cultivars (Regnault-Rogar et al., 1987).

Apart from the date fruit compounds, the phytochemical screening of palm leaf extracts generated prominent and valuable results, owing to the detection of alkaloids, flavonoids, phenols, phytosterols, tannins, amino acids, terpenoids, and carbohydrates possessing well-known curative action against several human pathogens (Nadia et al., 2013). Date sugars are phenol rich, potent antioxidants, and strong inhibitors of $\alpha$-glycosidase and $\alpha$-amylase (Ranilla et al., 2008). The date fruit exhibits its potential use against cardio and cerebrovascular diseases (CCVD) as identified through preliminary experimental evidence, playing a significant role in blocking events that occur during the initiation and progression of CCVD, primarily by reducing hyper- 
tension, hypercholesterolemia, and oxidation of lipoproteins, enhancing serum antioxidant status, alleviating the harmful effects of oxidative stress, and probably, inflammation on the vascular system (Vayalil, 2012). Anjum et al., 2012, conducted a study to determine the total phenolic and antioxidant activity of three Pakistani date cultivars, Dora, Dhakki, and Karbaline. The results revealed that the methanolic extract of Karbaline exhibited the highest percentage yield $(5.01 \pm 0.75 \%)$ of non-volatile extracts on weight/weight $(\mathrm{w} / \mathrm{w})$ basis, "Dora" had highest total phenolic content (55.648 $\pm 0.11 \mathrm{mg} \cdot \mathrm{g}^{-1}$ dry extract) and methanolic extract of "Karbaline" (90.96\%) showed the highest inhibition of free radical generation by1,1-diphenyl-2-picrylhydrazyl (DPPH) assay. Hence, the study concluded that date palm fruit has good antioxidant potential and can be used to produce novel natural antioxidants as well as flavoring agents that can be used in various food products.

Inhibition of lipid peroxidation, protein oxidation, and a potent hydroxyl radical scavenging activity have been exhibited by aqueous extracts of dates (Allaith, 2005). A study investigated the chemical composition, mineral extractability, and antioxidant capacity of six date palm cultivars (Barakawi, Gondaila, Jaw, Mishrig, Bittamoda, and Madini) grown in Sudan. The results revealed the presence of a high amount of total polyphenols in Madini and total flavonoids in Gondaila date cultivars under analysis. Moreover, the luorescence Recovery after Photobleaching chelation of $\mathrm{Fe}^{2+}$ ion and $\mathrm{H}_{2} \mathrm{O}_{2}$ scavenging of fruits demonstrated moderate to high values that varied between cultivars (Mohamed et al., 2014)

It is well-known that consumers are constantly in search of healthy and nutritional foods and the consumption of date fruits which have antioxidantproperties can be increased. Fahad et al., (2015) carried out a study to analyze the total phenolic content, antioxidant potential, and color in six commercially available date cultivars in the USA. They were: "Deglet Nour" cultivated in California (DNC), "Deglet Nour" imported from Tunisia (DNT), "Deglet Nour" imported from Algeria (DNA), "Khudri" imported from Saudi Arabia (KSA), "Barni" imported from Saudi Arabia (BSA), and "Shahia" imported from Tunisia (SHT). The results of this study revealed that the total phenolic content varied from 33 to $125 \mathrm{mg}$ gallic acid equivalents (GAE)/100 g of dry weight, the highest being in "Barni" (BSA). Antioxidant values determined by $2,2^{\prime}$-azino-bis(3-ethylbenzothiazoline-6-sul- phonic acid) assay in DNA, DNC, DNT, SHT, BSA. and KSA were found to be $1300,1047,796,452,776$, and $341 \mu \mathrm{mol}$ Trolox equivalents (TE) $\cdot \mathrm{g}^{-1}$ dry weight, respectively. The color of the date fruit is considered an important parameter affecting consumer acceptability and is also an important quality parameter in commercial date fruits. In this study, "Deglet Nour" from California showed a lighter fruit and pulp color when compared to other five cultivars and was, therefore, considered better in terms of color.

In another study performed by Ghiaba et al., (2012), methanolic extracts from five cultivars of date palm fruit from Algeria, namely, "Deglet Nour" (DN), "Degla Baidha” (DB), "Ghars" (Gh), "Tamjhourt" (Tam), and "Tafezauine" (Taf) were analyzed for their phenolic content as well as their antioxidant activities. The total phenolic content ranged from 41.80 to $84.73 \mathrm{mg} \mathrm{GAE} / 100 \mathrm{~g}$ and the antioxidant values, evaluated in vitro using DPPH radical scavenging assay, ranged from 10.83 to $21.27 \mathrm{mg} \cdot \mathrm{l}^{-1}$. The effective scavenging concentration $\left(\mathrm{IC}_{50}\right)$ values decreased in the following order: $\mathrm{DN}>\mathrm{Gh}>\mathrm{Tam}>\mathrm{DB}>$ Taf. These results suggest that methanol extracts of date palm fruits contain considerable quantities of phenolic compounds and possess a good antioxidant activity which may be associated with their supposed health benefits (Ghiaba et al., 2012). Hanen et al., (2018), evaluated the antioxidant, anti-inflammatory, and antitumoral potential of $P$. dactylifera L. parthenocarpic dates using DPPH radical scavenging assay, inhibition of phospholipase $\mathrm{A}_{2}$ activity, and 3-4,5-dimethylthiazol-2-yl-2,5-diphenyltetrazolium bromide (MTT) assay respectively. Results confirmed the ethnopharmacological significance of dates, showing a strong scavenging activity against the DPPH radical (94\%) and capability of inhibiting the growth of cancer cells with $\mathrm{IC}_{50}$ values of 8 and $18 \mathrm{mg} \cdot \mathrm{ml}^{-1}$ respectively for MDA-MB-231 and MCF-7 breast cancer cell lines.

\section{Therapeutic applications of dates}

In addition to the nutritional values, date fruits are believed to have medicinal properties when consumed either alone or in combination with herbs. In recent years, a sudden increase of interest in the abundant health benefits of dates has led to many in vitro and animal studies, as well as the detection and quantification of various classes of phytochemicals (Vayalil, 2012). The antioxidant potential of date fruit is attributed to the presence of multiple bioactive compounds called phyto- 
chemicals that help to fight against oxidative stress caused by the generation of free radicals in cells.

\section{Protection against diabetes mellitus}

Diabetes mellitus (DM) is a chronic metabolic disorder, caused by deficiency, either inherited or acquired, in the production of insulin by the pancreas, resulting in higher concentrations of glucose in blood which, in turn, may cause other serious metabolic disorders resulting in damage to nerves and vessels (Nagappa et al., 2003). Seyyed et al., (2010), investigated the glycemic index of the $P$. dactylifera leaf extract (PDE) and its fractions in wistar rats in whom diabetes was induced by alloxan monohydrate. The control animals were given saline, whereas the animals from the treatment groups were given different doses of PDE, once a day for 14 days. Biochemical screening of all tested groups revealed that some of the properties of PDE or its sub-acute administration, significantly reduced blood sugar levels $(P<0.01)$. Another study carried out by Hussein et al., (2015), investigated the defensive properties of date palm extracts on liver functions in type-2 diabetic rats and aimed at determining the phenolic and flavonoid content with the aid of HPLC. This was the first study that demonstrated the activity of aqueous and methanolic extracts of date palm fruits against hepatic dysfunction in type-2 DM containing different chemical groups. This study also revealed the presence of caffeic, gallic, ferulic, and sinapic acids as the phenolic compounds and apegenin, quercetin, and luteolin as the flavonoid compounds in the fruit extracts. Hanen et al., (2017) demonstrated in their experiment that $P$. dactylifera parthenocarpic dates act as a potent inhibitor of the enzyme related to type 2 diabetes. The in vitro study revealed that the date extract is a more specific inhibitor of $\alpha$-glucosidase with an $\mathrm{IC}_{50}$ value of $0.6 \mathrm{mg} \cdot \mathrm{ml}^{-1}$ as compared to $2.5 \mathrm{mg} \cdot \mathrm{ml}^{-1}$ for $\alpha$-amylase. This study also confirmed that the antipostprandial hyperglycemia activity of the extract could be supportive in its use as a therapeutic agent in the relevant field.

Daily consumption of dates is a deeply rooted tradition in many societies, including those in the United Arab Emirates (UAE). As reported, in Oman, which lies immediately adjacent to the UAE, there areabout 250 cultivars of date palms. Thirty of these cultivars are cultivated in large areas because of their high quality and consumer demand (Al-Yahyai and Al-Khanjari 2008).
Another research was designed to determine the glycemic indices of five commonly used cultivars of dates in healthy individuals and their effect on postprandial glucose excursions in individuals suffering with type 2 DM. The results of the study revealed that the tested cultivars of dates contributed to low glycemic indices in healthy subjects and that their consumption by diabetic individuals did not result in significant postprandial glucose excursions. In conclusion, when used in a healthy balanced diet for diabetic subjects, dates could lead to potential health benefits (Juma et al., 2011).

\section{Hepatoprotective activity}

Liver diseases have become a world-wide problem and a significant threat to public health, being indigenous to developing countries (Adewusi and Afolayan, 2010). To appraise the hepatoprotective activity of methanolic fruit extract of $P$. dactylifera against thioacetamide induced liver damage, tests were conducted in albino wistar rats. The results revealed that the extracttreated groups had significantly lower mean values for the biomarkers of liver injury like aspartate aminotransferase, alanine aminotransferase, alkaline phosphatase, bilirubin, and albumin when compared with the thioacetamide control group (Chukwugozie et al., 2014).

Another study was designed by Bashandy et al., (2016) for determining the protective effects of date palm extract against cerastes-venom-induced oxidative stress and biochemical changes in the liver of 104 male wistar albino rats. The animals were treatedwith date palm extract and different doses of venom were used during the study. The results revealed that the administration of the date palm extract provided hepatoprotective effect against damage caused by the venom by obstructing oxidative stress through the reactive oxygen species (ROS) scavenger and improvement in biochemical markers.

\section{Anticancer properties of dates}

Free radicals, referred to as highly reactive particles with unpaired electrons, are known to implicate oxidative stress in the pathogenesis of a great variety of clinical disorders such as cancer, CVD, Alzheimers disease, DM, multiple sclerosis, and arthritis (Halliwell and Gutteridge, 1999). Ramazania et al., (2016), examined the activity of different concentrations of aqueous and $n$-hexane extracts of date fruit in the proliferation of 
A2780, A172, and HFFF2 cell lines by means of MTT assay. As revealed in this study, the $n$-hexane extract of dates showed increased activator effects on the cell lines as compared to aqueous extracts, in a dose dependent manner, which was further explained by the presence of active compounds found in n-hexane extracts. The effects of crude extracts of fruit and pits of date palm were evaluated by Al-Ani et al., (2013), on two malignant cell lines, human laryngeal carcinoma (Hep2), and murine mammary adenocarcinoma (AMN3), and one normal cell line, rat embryo fibroblast. The evaluation of the influence of the fruit extract on certain cytogenetic parameters such as mitotic index \%), blast index (\%), and chromosomal aberrations was done on peripheral blood lymphocytes cultured in vitro. The results revealed that crude extracts of the date palm fruit exhibited time and concentration-dependent cytotoxic effects on the in vitro cell growth assay, whereas crude extracts of pits stimulated the effects on Hep2 and AMN3 cell lines. It was also proved that both, aqueous extracts of fruits and ethanolic extracts of pits,showed slight growth inhibitory effects on normal cell lines, whereas a high inhibition in growth was observed in some cancerous cell lines, which clearly indicated the relevance of both extracts against malignant cell lines (Al-Ani et al., 2013); Yasin et al., (2015) summarized, in a review article, the therapeutic effects of the date palm fruit in preventing cell damage, improving cancer therapeutics, and reducing damage caused by conventional chemotherapy. In conclusion, this research suggested a potential application of the $P$. dactylifera fruit to more complex mammalian systems in order to solve several problems of chemotherapy in hepato-compromised and nephro-compromised patients.

\section{Neuroprotective activity of dates}

$P$. dactylifera imparts crucial physical benefits to the brain. They are neuroprotective or cerebroprotective effects which protect the brain from the destructive activities of the reactive ROS that arise from cell metabolism itself or from (Steinbrenner and Sies, 2009). A study done by Ismail and Radzi, (2013) evaluated the benefits of the date fruit and date seed extracts in cerebral ischemia induced in rat brains. This work concluded that a great reduction in neuronal damage, in the form of shrinkage, atrophy, and necrosis of neurons, occurred and was accompanied by an accelerated production of endogenous antioxidants in the brain of rats treated with date palm fruit extract. $P$. dactylifera significantly benefited the brain by itsneuroprotective effects, with its antioxidant compounds and fatty acids protecting the brain from the action of reactive oxygen species (Ismail and Radzi, 2013).

Vyawahare et al., (2009b), evaluated the effect of methanolic extracts of $P$. dactylifera on the neurobehavioral characteristics of mice including locomotor activity, exploratory behavior, motor co-ordination, hot-plate test, haloperidol-induced catalepsy, sodium-nitrite induced respiratory arrest, and maximum electroshockinduced convulsions. The results of the study provided evidence that different doses of the methanolic extract of the $P$. dactylifera fruit, studied in several neuropharmacological models, possess a wide spectrum of a central nervous system activity. Awwad and Hussain, (2015) conducted a study that dealt with cerebral ischemia-reperfusion induced oxidative stress and histopathological alternations in rats on the application of an aqueous extract of a specific variety (sukari) of the date fruit. The results of this study revealed that the aqueous extracts of sukari dates have potential benefits in the treatment of stroke and ischemia-reperfusion injury.

\section{Conclusions}

Owing to its nutritional and medicinal properties, the fruit of $P$. dactylifera has been referred to as "super food" in the Quran. Due to its incredible nutritional value and presence of multiple phytochemicals, it may be considered as a potential low-cost dietary supplement. In addition, the antioxidant profiles of different cultivars of date palm revealed its significant role in reducing oxidative stress, thereby preventing cancer, liver disorders, as well as cardiovascular and neurological diseases. However, only further research related to synergistic studies of this fruit along with other valuable plant products can establish the real benefits of this species in combating various types of deadly diseases.

\section{References}

Abdelhak M., Guendez E., Engene K., Panagiotis K. (2005) Phenolic profile and antioxidant activity of the Algerian ripe date palm fruit (Phoenix dactylifera). Food Chem. 89: 411-420.

Adewusi E.A., Afolayan A.J. (2010) A review of natural products with hepatoprotective activity. J. Med. Plants Res. 4(13): 1318-1334. 
Al Harthi S.S, Mavazhe A., Al Mahroqi H., Khan S.A. (2015) Quantification of phenolic compounds, evaluation of physicochemical properties and antioxidant activity of four date (Phoenix dactylifera L.) varieties of Oman. J. Taibah Univ. Med. Sci. 10(3): 346-352.

Al-Ani B.A., Yassin N.Y., Al-Juraisy Y.H. (2013) Effect of crude extracts of date pits (Phoenix dactylifera L. cv. zahdi) on some cancer cell lines in vitro and their effect on human lymphocytes and treatment of transplanted mammary adenocarcinoma in mice. J. Uni. Anbar Pure Sci. 7(2): 1-10.

Al-Farsi M., Alasalvar C., Morris A., Baron M., Shahidi F. (2005) Comparison of antioxidant activity, anthocyanins, carotenoids and phenolics of three native fresh and sun dried date (Phoenix dactylifera $L$ ) varieties grown in Oman. J. Agri. Food Chem. 53(11): 7592-7599.

Al-Fuhaid K.M. (2006) The famous date varieties in the king dom of Saudi Arabia. Ministry of Agriculture. First edition. Public Relation and Agriculture Information, FAO: 245.

Al-Gboori B., Krepl V. (2010) Importance of date palms as a source of nutrition. Agricultura Tropica et Subtropica 43(4): 341-347.

Allaith A., Abdull A. (2005) In-vitro evaluation of antioxidant activity of different extracts of Phoenix dactylifera $L$. fruit as functional foods. Deutsche Lebensmittel Rundschau. 101: 305-308.

Al-Shahib W., Marshall R.J. (2003) The fruit of the date palm: it's possible use as the best food for the future. Int. J. Food Sci. Nutr. 54: 247-259.

Alwarthan A.A., Alswaidan H.M. (1995) Determination of trace elements in Saudi Arabian dates by inductively coupled plasma-mass spectrometry. Arab. Gulf J. Sci. Res. 13(3): 453-461.

Al-Yahyai R. (2012) An overview of date palm production. [in:] Dates: Production, processing, food and medicinal values. Ed. Manickavasagan A., Essa M.M., Sukumar E. UK: CRC press: 3-12.

Al-Yahyai R., Al-Khanjari S. (2008) Biodiversity of date palm in the Sultanate of Oman. Afr. J. Agric. Res. 3(6): 389-395.

Anjum F.M., Bukhat S.I., EI-Ghorab A.H., Khan M.I., Nadeem M. (2012) Phytochemical characteristics of date palm (Phoenix dactylifera) fruit extracts. Pak. J. Food Sci. 22: 117-127.

Awwad I.A., Hussain S.M. (2015) Exploring the possible role of date fruit (Phoenix dactylifera L.) extract in amelioration of stroke in rats. Asian J. Biomed. Pharma. Sci. 5(51): 31-35.

Baliga M.S., Baliga B.R.V., Kandathil S.M., Bhat H.P., Vayalil P.K. (2011) A review of the chemistry and pharmacology of the date fruits (Phoenix dactylifera L.). Food Res. Int. 44: 1812-1822.

Bashandy M.A., Abd-el-aal A.M., Ibrahim D.F., El-sharkawy M.A. (2016) Protective effects of date palm extract as natural antioxidants on hepatotoxicity induced by cerates venom in albino rats. Int. J. Adv. Res. 4(3): 647-665.

Benmeddour Z., Mehinagic E., Le Meurlay D., Louaileche H. (2013) Phenolic composition and antioxidant capacities of ten Algerian date (Phoenix dactylifera L.) cultivars: a comparative study. J. Func. Foods. 5: 346-354.

Bircher W.H. (1990) The date palm; A Boon for Mankind. Cairo University Herbarium, Egypt: 100.

Botes A., Zaid A. (2002) The economic importance of date production and international trade. [in:] Date palm cultivation. Ed. Zaid A., Arias-Jimenez E.J. FAO plant production and protection paper, 156 rev.1. FAO: Rome.

Chandler W. (1958) Evergreen orchards. Lea \& Fabiger, Philadelphia: 563-564.

Chevalier A. (1952) Recherches surles Phoenix africains. Rev. Int. Bot. Appl. Agric. Trop. 355-356.

Christenhusz M.J.M., Byng J.W. (2016) The number of known plants species in the world and its annual increase. Phytotaxa. 261(3): 201-217.

Chukwugozie N.O., Theophilus K.U., Augustine C.O., Innocent C.A., Romanus E.M. (2014) Hepatoprotective effect of methanolic fruit extracts of Phoenix dactylifera (Arecaceae) on thioacetamide induced liver damage in rats. Amer. J. Phytomed. Clin. Ther. 2(3): 290-300.

Elleuch M., Besbes S., Roiseux O., Blecker C., Deroanne C., Drira N.E., Attia H. (2008) Date flesh: chemical composition and characteristics of the dietary fiber. Food Chem. 111(3): 676-682.

El-Sohaimy S.A., Hafez E.E. (2010) Biochemical and nutritional characterization of date palm fruits (Phoenix dactylifera L.). J. Appl. Sci. Res. 6(8): 1060-1067.

Fahad M.A.J., Muhammad S., Dalbir S.S. (2015) Antioxidants activity and color evaluation of Date fruit of selected cultivars commercially available in the United States. Adv. Chem. 1-5.

Ghiaba Z., Mustapha B., Amar D., Mohktar S., Mohamed Y. (2012) Screening of antioxidant activity and phenolic compounds of various date palm (Phoenix dactylifera) fruits from Algeria. Mediterr. J. Nutr. Metab. 5: 119-126.

Golshan T.A., Solaimani D.N., Yasini A.S.A. (2017) Physicochemical properties and applications of date seed and its oil. Int. Food Res. J. 24(4): 1399-1406.

Halliwell B., Gutteridge J.M.C. (1999) Free Radicals in Biology and Medicine. Ed. Halliwell B., Gutteridge J.M.C., Oxford University Press: Oxford: 1-25.

Hanen E.A., Mouna C., Zaineb A.K., Noureddine D., Naziha M., Hafedh M., Bassem K. (2018) Antioxidant, anti-inflammatory, and antitumoral effects of aqueous ethanolic extract from Phoenix dactylifera L. parthenocarpic dates. BIOMED Res. Int. (18): 1-7.

Hanen E.A., Mouna C., Imen F., Mohamed M., Mohamed B., Noureddine D., Hafedh M., Bassem K. (2017) Extraction optimization and in-vitro and in-vivo anti-postprandial hyperglycemia effects of inhibitor from Phoenix dactylifera $L$. parthenocarpic fruit. BIOMED Pharmacother. 88: 835-843.

Hussein A.M., El-Mousalamy A.M.D., Hussein S.A.M., Mahmoud S.A. (2015) Effects of palm dates (Phoenix dactylifera L.) extracts on hepatic dysfunctions in type 2 diabetic rat model. World J. Pharm. Pharm. Sci. 4: 62-79. 
Ismail W.W.I., Radzi M.N.F. (2013) Evaluation on the benefits of date palm (Phoenix dactylifera) to the Brain. Altern. Integ. Med. 2(4): 115.

Jassim S.A., Naji M.A. (2010) In vitro evaluation of the antiviral activity of an extract of Date Palm (Phoenix dactylifera L.) pits on a Pseudomonas Phage. Evid. Based Complement. Alternat. Med. 7: 57-62.

Juma M.A., Bayan A.D., Shakeel A., Hussein F.S., Salah G., Mustafa A.G. (2011) Glycemic indices of five varieties of dates in healthy and diabetic subjects. Nutr. J. 10: 59.

Lairon D., Arnault N., Bertrais S. (2005) Dietary fiber intake and risk factors for cardiovascular disease in French adults. Am. J. Clin. Nutri. Rev. 82: 1185-1194.

Liu S., Stampfer M.J., Hu F.B. (1999) Whole-grain consumption and risk of coronary heart disease: results from the Nurses' Health study. Am. J. Clin. Nutri. Rev. 70: 412-419.

Mohamed R.M.A., Fageer A.S.M., Eltayeb M.M., Ahmed I.A.M. (2014) Chemical composition, antioxidant capacity and mineral extractability of Sudanese date palm (Phoenix dactylifera L.) fruits. Food Sci. Nutr. 2(5): 478-489.

Montonen J., Knekt P., Jarvinen R., Aromaa A., Reunanen A. (2003) Whole-grain, and fiber intake and the incidence of type 2 diabetes. Am. J. Clin. Nutri. Rev. 77: 622-629.

Morton J. (2011) Date: Fruits of warm climates. Miami (FL): $5-11$.

Munier P. (1973) Le palmier-dattier. Maisonneuve and Larose, Paris: 221.

Nadia K.J., Al-Dawah S., Ibrahim L. (2013) Phytochemical characteristics of Date Palm (Phoenix dactylifera L.) leaf extracts. Kufa J. Vet. Sci. 4(1): 90-95.

Nagappa A.N, Thakurdesai P.A., Raob N.V., Singh J. (2003) Antidiabetic activity of Terminalia catappa Linn fruits. J. Ethnopharma. 88: 45-50.

Nixon R.W. (1951) The date palm "Tree of Life" in the subtropical deserts. Econ. Bot. 5: 274-301.

Penry J.T., Manore M.M. (2008) Choline: an important micronutrient for maximal endurance - exercise performance? Int. J. Sport. Nutr. Exerc. Metab. 18: 191-203.

Petruzziello L., Iacopini F., Bulajic M., Shah S., Costamagna G. (2006) Uncomplicated diverticular disease of the colon. Alimentary. Pharmacol. Ther. 23: 1379-1391.

Pliny C. (1489) The elder. Trans. Historia naturale, Book XIII, cap. iii, 3 columns on the palmae. Translated into Italian by Cristofore L. F. and published by Bartolamio de Zani de Portesio.

Popenoe P. (1973) The Date Palm. In: Field H. (Ed.), Field Research Projects, Coconut Grove, Miami, Florida, U.S.A.

Qudama A. (1985) Dictionary of food and treatment with plants. Beirut, Lebanon: 113.

Ramazania A., Mashhadib M., Kamalinejadc M., Tavakolizadehd M., Balaghib F., Noubaranib M., Eskandarib M.R., Shiraz F.H. (2016) Phoenix dactylifera L. Fruit Induces Cell Proliferation of A2780, A172 and HFFF2 Cell Lines. Iranian J. Pharma. Sci. 12(1): 35-44.

Randhir R., Lin Y.T., Shetty K. (2004) Stimulation of phenolics, antioxidant and antimicrobial activities in dark germi- nated mung bean sprouts in response to peptide and phytochemical elicitors. Process Biochem. 39: 637-646.

Ranilla L.G., Kwon Y.I., Genovese M.I., Lajolo F.M., Shetty K. (2008) Antidiabetes and antihypertension potential of commonly consumed carbohydrate sweeteners using in vitro models. J. Med Food. 11(2): 337-348.

Regnault-Roger C., Hadidan R., Biard J.F., Boukef K. (1987) High performance liquid and thin chromatographic determination of phenolic acids in palm (Phoenix dactylifera L.). Food Chem. 25: 61-71.

Rehm S., Espig G. (1977) Die Kulturpflanzen der Tropen und Subtropen. J. Plant Nutr. Soil Sci. 140(2): 249-250.

Sawaya W.N., Miski A.M., Kalil J.K., Khachadourian H.A., Mashadi A.S. (1983) Physical and chemical characterization of major date varieties grown in Saudi Arabia 1-morphological measurements, proximate and mineral analysis. Date Palm J. 2(1): 1-25.

Seyyed A.M., Kowthar J., Masoumeh J., Hoda B., Mohammad K.G.N. (2010) Evaluation of the antidiabetic and antilipaemic activities of the hydroalcoholic extract of Phoenix dactylifera palm leaves and its fractions in alloxan-induced diabetic rats. Malays. J. Med. Sci. 17(4): 4-13.

Steffen L.M., Jacobs D.R., Stevens J., Shahar E., Carithers T., Folsom A.R. (2003) Associations of whole-grain, refined grain, and fruit and vegetable consumption with risks of allcause mortality and incident coronary artery disease and ischemic stroke: the Atherosclerosis Risk in Communities (ARIC) Study. Am. J. Clin. Nutr. Rev. 78: 383-390.

Steinbrenner H., Sies H. (2009) Protection against reactive oxygen species by selenoproteins. Biochim. Biophys. Acta. 1790: $1478-1485$.

Swingle W.T. (1928) Metaxenia in the date palm, possibly a hormone action by the embryo or endosperm. J. Hered. 19: 257-268.

Tahraoui A., El-Hilaly J., Israili Z.H., Lyoussi B. (2007) Ethnopharmacological survey of plants used in the traditional treatment of hypertension and diabetes in south-eastern Morocco (Errachidia province). J. Ethnopharmacol. 110: $105-117$.

Uhl N.W., Dransfield J. (1987) Genera Palmarum: a classification of palms based on the work of Harold E., Moore J.L., Bailey H. [in:] Hortorium and the International Palm Society. Allen Press. Kansas: 214-217.

Van Zyl H.J. (1983) Date cultivation in South Africa. [in:] Information Bulletin No. 504: Compiled by the fruit and Fruit Technology Research Institute. Department of Agriculture, Stellenbosch, RSA: 26.

Vayalil P.K. (2012) Date fruits (Phoenix dactylifera Linn.): an emerging medicinal food. Crit. Rev. Food Sci. Nutr. 5: 249-271.

Vinson J.A., Zubik L., Bose P., Samman N., Proch, J. (2005) Dried fruits: excellent in vitro and in vivo antioxidants. J. Am. Coll. Nutr. 24: 44-50.

Vyawahare N., Pujari R., Khsirsagar A., Ingawale D., Patil M., Kagathara V. (2009a) Phoenix dactylifera: an update of its indigenous uses photochemistry and pharmacology. Int. J. Pharma. 7(1): 1531-2976. 
Vyawahare N.S., Pujari R.R., Rajendran R., Khsirsagar A.D., Ingawale D.K., Patil M.N. (2009b) Neurobehavioral effects of Phoenix dactylifera in mice. J. Young Pharm. 1(3): 225-232.

WCSP (2013) World Checklist of Selected Plant Families. Facilitated by the Royal Botanic Gardens, Kew. http:// apps.kew.org/wcsp/.

Whelton S.P., Hyre A.D., Pedersen B., Yi Y., Whelton P.K., He J. (2005) Effect of dietary fiber intake on blood pressure: a meta analysis of randomized, controlled clinical trials. J. Hypertens. 23: 475-481.

Yasin B.R., El-Fawal H.A.N., Mousa, S.A. (2015) Date (Phoenix dactylifera) polyphenolics and other bioactive com- pounds: a traditional Islamic remedy's potential in prevention of cell damage, cancer therapeutics and beyond. Int. J. Mol. Sci. 16: 30075-30090.

Zaid A., De Wet P.F. (2002) Botanical and systematic description of the date palm. [in:] Date palm cultivation. Ed. Zaid and Arias-Jimenez. FAO Plant Production and Protection Paper 156 Rev. 1. Rome, Italy: 57-72.

Zohary D., Hopf M. (2000) Domestication of plants in the old world: The origin and spread of cultivated plants in West Asia, Europe and the Nile Valley. Oxon, UK. Oxford University Press: $1-8$. 